\title{
Physical activity in commuting, household, leisure time, or work: which domain is associated with lower stress in adult workers?
}

\section{Atividade física no deslocamento, domicílio, lazer ou trabalho: qual domínio se associa à menor ocorrência de estresse em adultos trabalhadores?}

\author{
Marina Christofoletti dos Santos¹, Giovâni Firpo Del Duca', Elusa Santina Antunes de Oliveira², Mauro Virgílio Gomes de

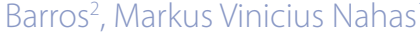

\begin{abstract}
The aim of the study was to investigate the association of the physical activity domains and types of physical activity practiced during leisure time with the occurrence of stress in workers. This is a cross-sectional survey, conducted from 2006 to 2008 , with a representative sample of industrial workers (n $=47,477 ; 69 \%$ men). Data were collected via questionnaire. For statistical analysis, a Poisson regression with adjustment for robust variance was used in Stata 13.0. Women who were physically active during leisure time (19.9\%; IC95\%: 19.0-20.7) had lower occurrences of stress than those who were physically inactive in this domain (14.2\%; IC95\%: 13.3-15.2). Among men, those active at home (11.6; IC95\%:11.1-12.0 vs. $12.9 \%$; IC95\%:12.4-13.5), during leisure time (10.2\%; IC95\%: 9.8-10.6 vs. $15.1 \%$; IC95\%: $14.4-15.7)$, and at work (11.7\%; IC95\%: 11.3-12.1 vs. $13.3 \%$; IC95\%: 12.6-14.0) had lower occurrences of stress than their peers. As the number of domains that contained physical activity increased, stress occurrence tended to decrease for both sexes. The types of leisure time physical activities associated with a lower occurrence of stress in women were sports (11.1\%), gymnastics/weight lifting (13.2\%), and dance (14.5\%); similar results were observed for men who engaged in jogging (9.0\%), sports (9.7\%), and walking (10.1\%). Physical activity in the leisure time domain, for women and men workers, including sports practice among women and jogging among men, were associated with lower stress occurrences.
\end{abstract}

\section{Keywords}

Occupational Health; Motor Activity; Leisure Activities; Stress, Psychological; Epidemiologic Studies; Cross-sectional Studies.

\section{Resumo}

O estudo objetivon investigar a associação dos domínios da atividade física e dos tipos de atividade física praticadas no lazer com a ocorrência de estresse em trabalhadores. Trata-se de uma pesquisa transversal, realizada de 2006 a 2008, com uma amostra representativa de industriários ( $n=47.477 ; 69 \%$ do sexo masculino). $\mathrm{Os}$ dados foram coletados via questionário. $\mathrm{Na}$ análise estatística, empregou-se a Regressão de Poisson com ajuste para variância robusta, no programa Stata 13.0. As mulheres fisicamente ativas (19,9\%; IC95\%: 19,0-20,7) no lazer apresentaram menor ocorrência de estresse do que aquelas fisicamente inativas (14,2\%; IC95\%: 13,3-15,2). Entre os homens, aqueles fisicamente ativos no domicilio (11,6; IC95\%: 11,1-12,0 vs. 12,9\%; IC95\%: 12,4-13,5), no lazer (10,2\%; IC95\%: 9,8-10,6 vs. 15,1\%; IC95\%: 14,4-15,7) e no trabalho (11,7\%; IC95\%: 11,3-12,1 vs. 13,3\%; IC95\%: 12,6-14,0) apresentaram menores ocorrências de estresse daqueles fisicamente inativos. Houve uma tendência de redução do estresse em ambos os sexos conforme o incremento de domínios com a prática de atividade física. Os tipos de atividade física no lazer associados às menores ocorrências de estresse, nas mulheres, foram os esportes (11,1\%), a ginástica/musculação (13,2\%) e a dança (14,5\%) e, nos bomens, foram a corrida (9,0\%), os esportes (9,7\%) e a caminhada $(10,1 \%)$. Conclui-se que a atividade física no domínio do lazer, tanto em mulheres quanto em homens trabalhadores, assim como as práticas de esportes, entre as mulheres, e corrida, entre os homens, mostraram-se associadas às menores ocorrências de estresse.

\section{Palavras-chave}

Saúde do trabalhador; Atividade motora; Atividades de lazer; Estresse psicológico; Estudos epidemiológicos; Estudos transversais.

\section{Introduction}

Stress may be defined as the non-specific response of the body to any demand made upon it, it can have the

1 Federal University of Santa Catarina, Postgraduate Program in Physical Education, Florianópolis, Santa Catarina, Brazil

2 University of Pernambuco, Postgraduate Program in Physical Education, Recife, Pernambuco, Brazil consequence of producing positive or negative reactions in the body generated by physical or psychosocial stressors ${ }^{1}$. In particular it may affect an individual's emotions, their mood or their behavior, as well as various biological systems and organs and tissues. This is primarily due to the continuous release of glu- 
cocorticoid hormones, such as cortisol, the increased concentration of which interferes incisively with the subject's routine $e^{2,3}$. In the epidemiological panorama, approximately $14 \%$ of chronic diseases are the result of neuropsychiatric disorders ${ }^{4,5}$, like stress, which can originate from different sources, such as the occupational setting ${ }^{6-8}$, post-traumatic ${ }^{5}$ or chronic periods ${ }^{9}$, and other classifications drawn from the interpretation of the duration and dimension of the stress observed ${ }^{7}$.

Non-drug treatment for stress such as regular physical activity, as well as breathing techniques and meditation have proven to be effective ${ }^{9,12}$. Physical activity can promote psychological well-being and mental health, and also has acute effects, such as the release of endorphins and increased oxygenation to the neural system ${ }^{2}$. It can also be used to prevent emotional imbalances, as well as to treat people with stress ${ }^{9}$. The existing literature recommends sessions with controlled intensity and of longer durations ${ }^{9}$, with aerobic activity (50 to 85\% HRmax), breathing ${ }^{13}$, and strength $(60 \text { to } 85 \% 1 \mathrm{RM})^{8}$ and flexibility exercises ${ }^{9,13}$.

Although a strong relationship between stress, work and lifestyle has been established, as well as the impact of different domains of physical activity on mental health ${ }^{5,14,15}$, these variables are little explored in Brazil and in the industrial sector in general. The aim of this study therefore, was to investigate the association of the physical activity domains and the types of physical activity practiced during leisure time, with the occurrence of stress in workers.

\section{Methods}

This cross-sectional study is part of a research report entitled "Lifestyle \& Leisure Habits of Brazilian Industry workers"16, coordinated by the Social Service for Industry in partnership with the Research Center on Physical Activity and Health of the Federal University of Santa Catarina in the period from 2006 to 2008. The study population consisted of industrial workers from 24 Brazilian federal districts (also known as federative units or states). Three states (Rio de Janeiro, Sergipe and Piaui) did not participate in the study.

Sample size calculation and sampling procedures were performed independently for each federal district. To calculate the sample size, we used an estimated prevalence of physical inactivity of 45 percent, ${ }^{17}$; a sampling error parameter of 3 percentage points; a 95 percent confidence interval (CI); as well as a 50 percent increase for design purposes and a 20 percent increase for losses and refusals. The total size required for each state sample resulted in a total study sample of 52,774 workers.

The sampling was conducted in two steps. In step one, the industries were randomly and proportionally selected, considering the distribution of workers in large ( $\geq 500$ employees), medium (100-499 employees) and small ( $\leq 99$ employees) companies. In step two, workers were systematically selected from lists provided by the industries, and stratified according to the sample size required for each geographical region of the country ${ }^{16}$.

The data were collected via a questionnaire and validated for content, clarity, $\operatorname{logic}^{18}$, as well as for reproducibility. The questionnaire was administered by evaluators located throughout Brazil, who had been trained by means of videoconference. Each evaluator was responsible for administering the instrument to groups of three to 15 participants.

The occurrence of stress was assessed using the following question: "How do you rate the level of stress in your life?" The response categories presented to the participants (rarely stressed, sometimes stressed, almost always stressed, always 
stressed) were dichotomized, as in analogue studies ${ }^{17,19}$, and the occurrence of stress was defined as the selection of one of the two latter categories, that is, a positive self-perception in relation to the outcome variable.

Physical activity participation in different domains was assessed by using specific questions. Physical activity in commuting was assessed by the question: "How do you commute to work on most weekdays?” The participants who reported walking or using a bicycle to commute to work were considered to be physically active. When assessing the household domain, participants who gave a positive answer to the following question were considered to be physically active: "Do you usually do heavy household chores (wash windows, scrub floors, do laundry, clean house, do gardening work)?" We considered physically active during leisure time the participants who answered the following question with 'yes': "Do you regularly do some kind of physical activity during your leisure time, such as physical exercise (gymnastics, walking, jogging), sports, dance, or martial arts?". As regards the practice of physical activity at work, participants were classified according to their answer to the following question: pela questão: "Your activities at work can be described as: Response options available: "I spend most of the time sitting (a) and, at best, walk short distances; I perform moderate physical activities such as fast walking or manual tasks most of the day; I often perform intense physical activities (heavy work)". Since there was more than one response option for the variable 'work' - de to the description of the activities performed - we considered physically active all participants who selected one of the last two aforementioned alternatives.

In addition to investigating the practice of physical activity in all four domains (commuting, household, leisure time and work) as described above, we also assessed the main type of physical activity performed during leisure time by posing the following question: "What is the main type of physical activity that you perform during your leisure time?". Possible answers were: "Sports; Jogging; Fitness/ Gymnastics/Weight Lifting; Dance/Rhythmic Activities; Yoga/Tai Chi Chuan/ Stretching exercises; Martial Arts/ Combat sports; Walking; Cycling; Swimming/ Water aerobics; Other; Do not participate in any physical activity during leisure time". What is the reproducibility of physical activity measurements?

The questionnaires were optically scanned and the data were digitized using the Sphinx software (Sphinx Software Solutions Inc., Washington, United States). At this stage, we also manually checked the data for possible inconsistencies, which, when existent, were corrected individually. Data analysis was performed using Stata, version 9.0 (Stata Corporation, College Station, United States). Descriptive statistics included prevalence estimates and 95\% confidence intervals. For statistical analysis, we used a Poisson regression with adjustment for robust variance and sociodemographic factors (age, marital status, education level and family income), chosen because they are important confounding factors already established in the literature. These were categorized as shown in Table 1. We used backward selection to select the study variables, as well as a critical level of $\mathrm{p} \leq 0.20$ for retainment in the regression model, in order to avoid confusion in analyses stratified by sex, because of the different prevalences of both outcomes and exposures between men and women. Results with p-values $\leq 0.05$ were considered statistically significant.

This study was approved by the Ethics Committee of the Federal University of Santa Catarina (Opinion number 009/2007) and duly authorized by the Social Services for the Industry. All participants signed an Informed Consent Form (ICF). 
TABLE 1 - Physical activity participation in different domains and sociodemographic characteristics of Brazilian workers. Brazil, 2006-2008.

\begin{tabular}{|c|c|c|c|}
\hline Variable & $\mathrm{N}$ & $\%$ & $95 \% \mathrm{Cl}$ \\
\hline \multicolumn{4}{|l|}{ Sex } \\
\hline Female & 14316 & 30.2 & $(29.7-30.6)$ \\
\hline Male & 33161 & 69.8 & $(69.4-70.3)$ \\
\hline \multicolumn{4}{|l|}{ Age (full years) } \\
\hline$\leq 29$ & 21801 & 46.1 & $(45.7-46.6)$ \\
\hline $30-39$ & 14639 & 31.0 & $(30.5-31.4)$ \\
\hline$\geq 40$ & 10845 & 22.9 & $(22.6-23.3)$ \\
\hline \multicolumn{4}{|c|}{ Current marital status } \\
\hline Single & 20694 & 43.7 & $(43.3-44.1)$ \\
\hline In a relationship & 26664 & 56.3 & $(55.9-56.7)$ \\
\hline \multicolumn{4}{|c|}{ Education (years of schooling completed) } \\
\hline$\leq 7$ & 8969 & 18.9 & $(18.6-19.3)$ \\
\hline 8 & 7425 & 15.7 & $(15.3-16.0)$ \\
\hline $9-11$ & 24173 & 51.0 & $(50.6-51.5)$ \\
\hline$\geq 12$ & 6803 & 14.4 & $(14.0-14.7)$ \\
\hline \multicolumn{4}{|c|}{ Gross family income $(\mathrm{R} \$)^{*}$} \\
\hline$\leq 600$ & 15069 & 32.1 & $(31.7-32.5)$ \\
\hline 601 to 1500 & 19451 & 41.4 & $(41.0-41.8)$ \\
\hline$\geq 1501$ & 12461 & 26.5 & $(26.1-26.9)$ \\
\hline \multicolumn{4}{|c|}{ Physical activity in commuting } \\
\hline No & 34436 & 72.8 & $(72.4-73.2)$ \\
\hline Yes & 12852 & 27.2 & $(26.8-27.6)$ \\
\hline \multicolumn{4}{|c|}{ Physical activity at home } \\
\hline No & 16791 & 37.5 & $(37.1-38.0)$ \\
\hline Yes & 27941 & 62.5 & $(62.0-62.9)$ \\
\hline \multicolumn{4}{|c|}{ Physical activity during leisure time } \\
\hline No & 21392 & 45.4 & $(44.9-45.8)$ \\
\hline Yes & 25740 & 54.6 & $(54.2-55.1)$ \\
\hline \multicolumn{4}{|c|}{ Physical activity at work } \\
\hline No & 16660 & 35.3 & $(34.9-35.7)$ \\
\hline Yes & 30542 & 64.7 & $(64.3-65.1)$ \\
\hline \multicolumn{4}{|c|}{ Number of domains containing physical activity } \\
\hline None & 2837 & 6.4 & $(6.2-6.6)$ \\
\hline One & 10205 & 23.1 & $(22.7-23.5)$ \\
\hline Two & 15619 & 35.2 & $(34.9-35.7)$ \\
\hline Three & 12069 & 27.3 & $(26.9-27.7)$ \\
\hline Four & 3527 & 8.0 & $(7.7-8.2)$ \\
\hline
\end{tabular}

*Variable with the largest amount of information ignored by participants $(n=3,220)$.

\section{Results}

The initial number of industrial workers selected to participate in the study was 52,774 , effectively reaching $90.7 \%$ of the sample $(n=47.886)$. We excluded 409 participants because they did not report their sex in the questionnaire. Thus, the final sample analyzed included 47,477 workers. Most participants were males (69.8\%), lived with a partner (56.3\%), and had had at least nine years of education (51.0\%). 
A significant relative proportion of workers was young (age $\leq 29$ years: $46.1 \%$ ) and reported a gross family income between $\mathrm{R} \$ 601$ and $\mathrm{R} \$ 1,500$ (41.4\%).

The prevalence of stress in the total sample was 13.8\% (95\% CI: 13.5 - 14.1), and its occurrence was more prevalent in females (17.7\% [95\% CI:17.1 - 18.3]) than in males $(12.1 \%$; $95 \%$ CI: 11.8 - 12.5). With regard to the practice of physical activity in the analyzed domains, we found that most industrial workers were physically active at home (62.5\%; 95\% CI: 62.0-62.9), during leisure time (54.6\%; 95\% CI: 54.2-55.1), and at work (64.7\%; 95\% CI: 64.3-65.1). Conversely, most workers were physically inactive in the domain 'commuting', (72.8\%; 95\% CI: 72.4-73.2). Physical activity participation accumulated in two (35.2\%; 95\% CI: 34.9-35.7) or three (27.3\%; 95\% CI: 26.9-27.7) domains resulted in better results when compared with the other categories.

Women who were physically active women during leisure time had lower occurrences of stress than those who were physically inactive in this domain (19.9\%; $95 \%$ CI: 19.0-20.7 versus 14.2\%; 95\% CI: 13.3-15.2, respectively) - (Figure 1). Among men, those active at home (11.6\%; 95\% CI: $11.1-12.0$ versus $12.9 \%$; $95 \%$ CI: $12.4-$ 13.5, respectively), during leisure time (10.2\%; 95\% CI: 9.8-10.6 versus $15.1 \%$; $95 \%$ CI: $14.4-15.7$, respectively), and at work (11.7\%; 95\% CI 11.3-12.1 versus $13.3 \%$; 95\% CI: 12.6-14.0, respectively), had lower occurrences of stress than their peers, as shown in Figure 2. As the number of domains that contained physical activity increased, the occurrence of stress tended to decrease for both sexes, being more highly accentuated in men $(\mathrm{p}<0.001)$ - (Figure 3).

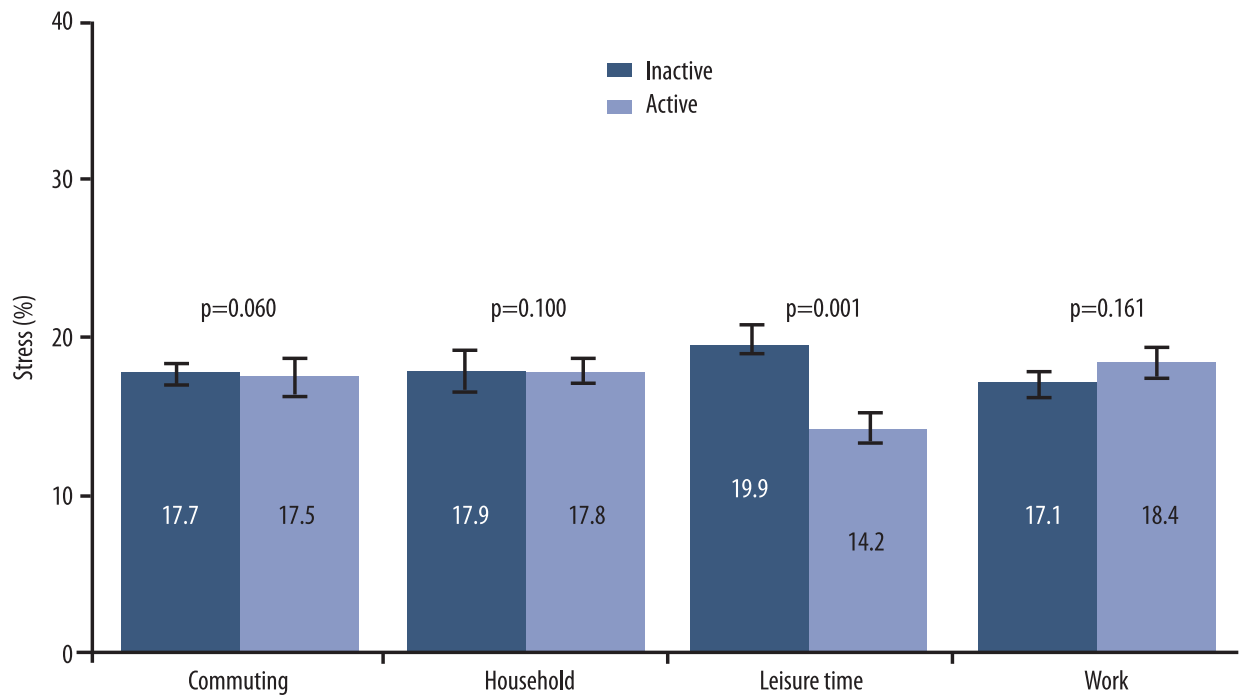

FIGURE 1 - Occurrence of stress in female Brazilian workers according to their physical activity participation in different domains. Brazil, 2006-2008.

* $p$-value, derived from Wald test for heterogeneity, adjusted for age, marital status, education level and family income.

The types of leisure time physical activities associated with a lower occurrence of stress in women were sports $(\mathrm{p}<0.001)$, gymnastics/weight lifting $(\mathrm{p}<0.001)$, dance $(\mathrm{p}=0.002)$, and walking $(\mathrm{p}<0.001)$ (Figure 4$)$. Similar results were observed for men who engaged in jogging $(\mathrm{p}<0.001)$, sports $(\mathrm{p}<0.001)$, walking $(\mathrm{p}<0.001)$, gymnastics/weight lifting $(\mathrm{p}<0.001)$, and cycling $(\mathrm{p}=0.001)$ - (Figure 5). 


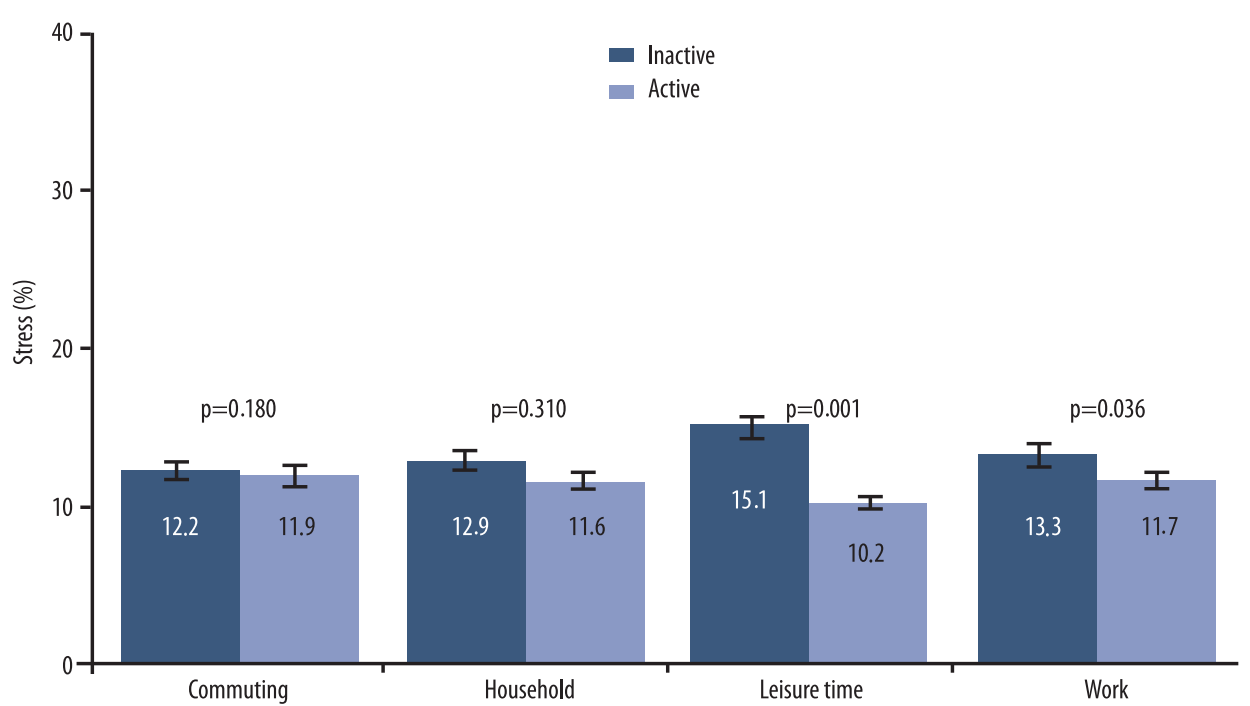

FIGURE 2 - Occurrence of stress in male Brazilian workers according to their physical activity participation in different domains. Brazil, 2006-2008.

${ }^{*}$ p-value, derived from Wald test for heterogeneity, adjusted for age, marital status, education level and family income.

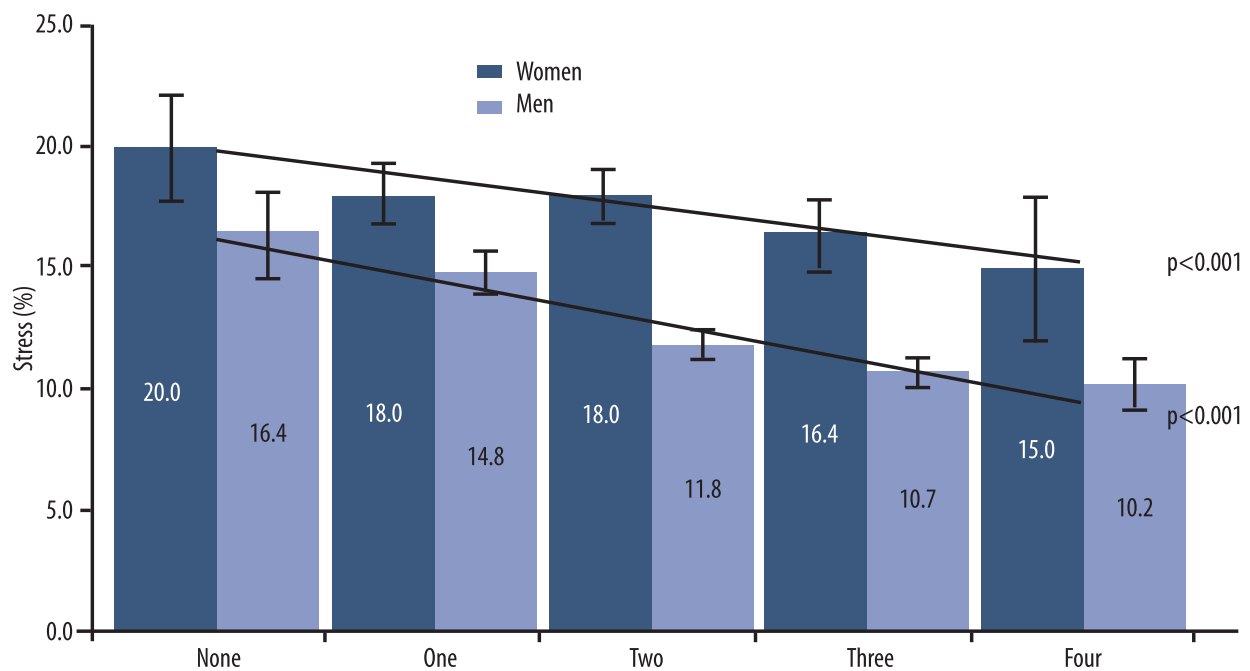

FIGURE 3 - Occurrence of stress in Brazilian workers according to their accumulated physical activity participation in different domains. Brazil, 2006-2008.

${ }^{*} \mathrm{p}$-value, derived from Wald test for heterogeneity, adjusted for age, marital status, education level and family income.

\section{Discussion}

In this study, the women who were physically active during leisure time had lower occurrences of stress than physically inactive women, whereas the men who were physically active at home, during leisure time and at work had lower occurrences of stress than their physically inactive peers. As the number of domains that contained physical activity increased, stress occurrence tended to decrease for both sexes. The types of leisure time physical activities associated with a lower occurrence of stress in women were sports, gymnastics/weight lifting, and dance; similar results were observed for men who engaged in jogging, sports, and walking.

The prevalence of stress in the total sample was $13.8 \%$. This is in line with other Brazilian studies conducted with industrial workers in the states of Santa Catarina ${ }^{17}$ and Pernambuco ${ }^{19}$, which found $13.9 \%$ and $11.1 \%$ prevalence, respectively. These results, however, are much lower than the results observed in studies carried out with 


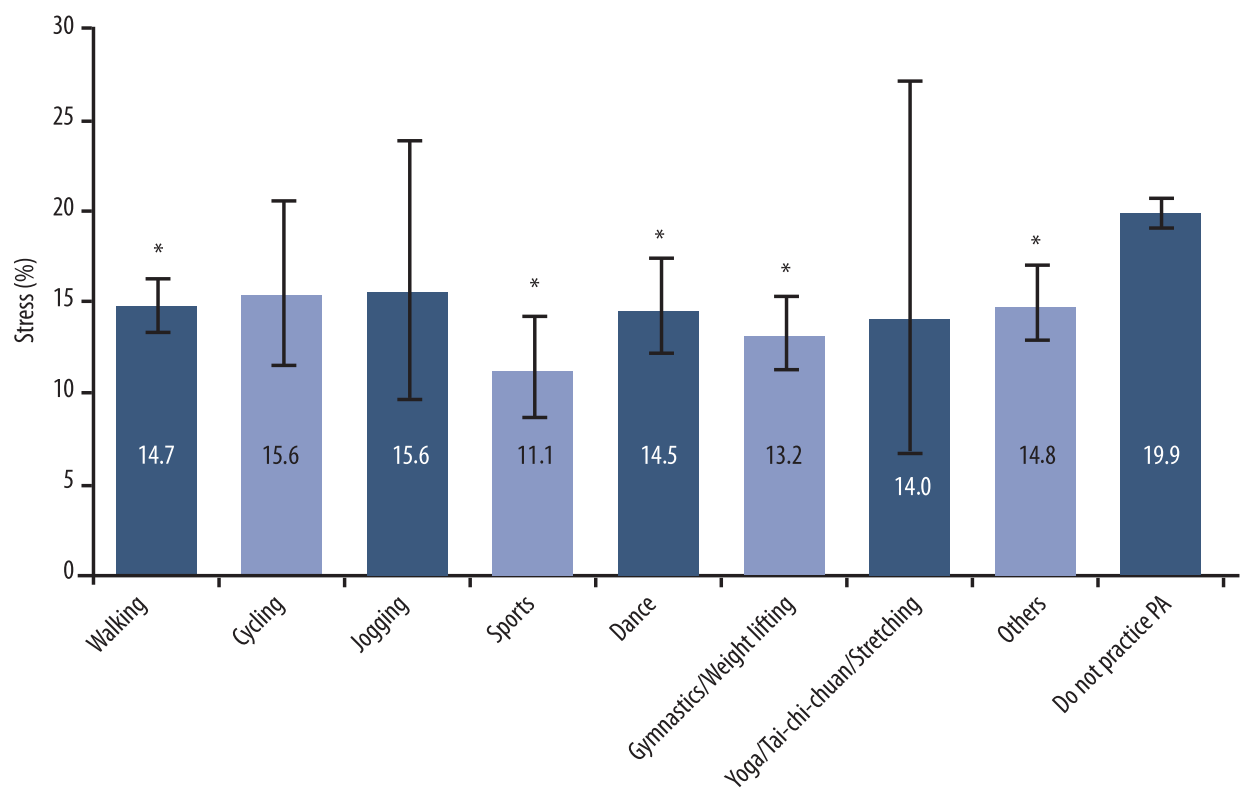

FIGURE 4 - Occurrence of stress in female Brazilian workers and types of physical activity performed by them during leisure time Brazil, 2006-2008.

* $p$-value, derived from Wald test for heterogeneity, adjusted for age, marital status, education level and family income.

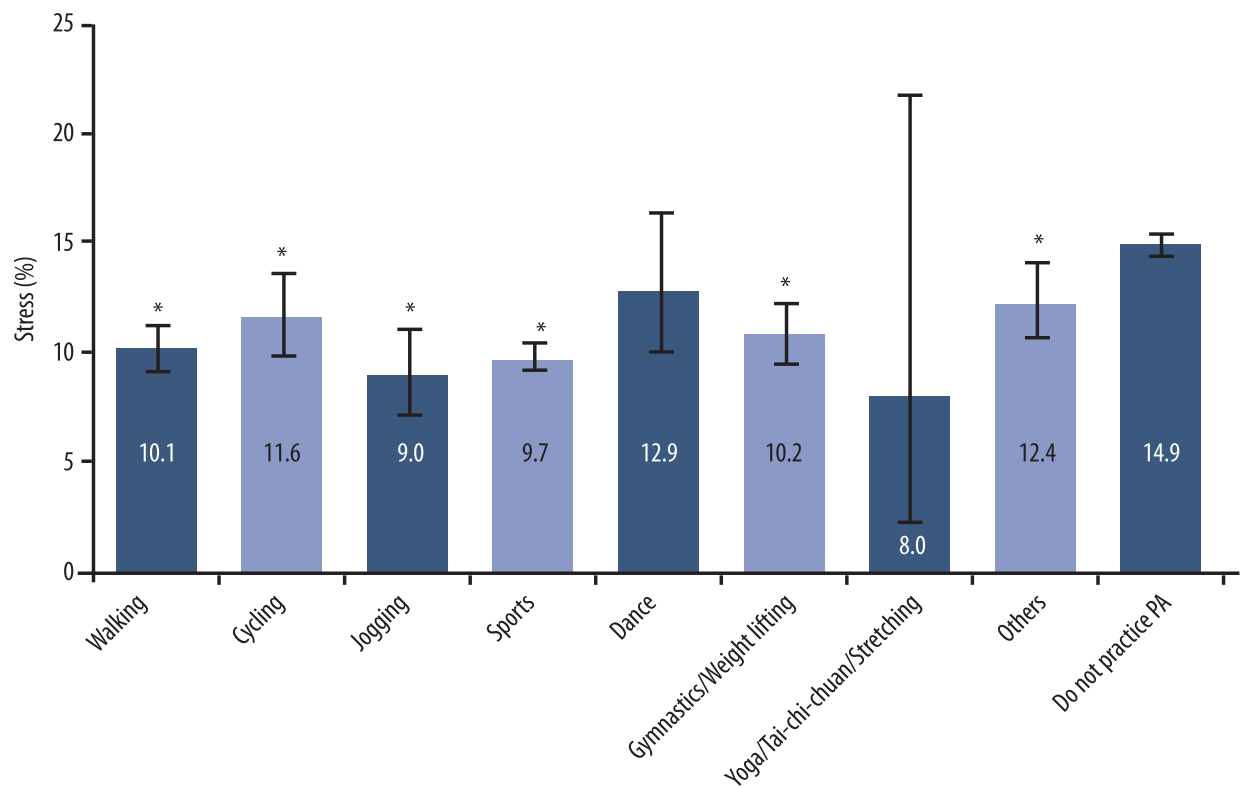

FIGURE 5 - Occurrence of stress in male Brazilian workers and types of physical activity performed by them during leisure time. Brazil, 2006-2008.

${ }^{*}$ p-value, derived from Wald test for heterogeneity, adjusted for age, marital status, education level and family income.

other worker populations in Brazil, such as judges ${ }^{20}$, public school teachers ${ }^{21}$, public health professionals ${ }^{2}$ and bankers $^{22}$. Keeping in mind but not further analyzing the specificities of the different forms of stress measurement used in these studies, it is possible to infer that profession may be a determining factor in the occurrence of stress ${ }^{10,23}$. This reflection may support future analyses, which, in turn, may result in the implementation of preventive measures that prioritize better quality of life for workers, regardless of their area of expertise or occupational position.

When investigating the association between the occurrence of stress and the different domains of physical activity, we found that, domestic activities were as- 
sociated with lower stress occurrences in men, whereas no association was found for women in this domain. This raises the question of whether women who take the major role at home, accumulating multiple functions and responsibility not only for household chores, but also caring for the entire family, suffer higher stress occurrences ${ }^{17}$. Men, culturally, tend to perform less complex household chores and do so less frequently than women. A study by Farah et al. ${ }^{19}$ found that women's double shifts were associated with a lack of opportunities and access to structured programs for stress management in adulthood, such as the chance to participate in physical exercise programs. This raises the importance of physical activity during leisure time for women's mental health.

Only physical activity in the leisure time domain was associated with lower stress occurrences both for female and male workers. This finding is consistent with a study by Otha et al. ${ }^{24}$, which found that participation in physical activity outside work hours was a predictor of better mental health in Japan's civil servants. This domain plays a key role in occupational health, because it is a time reserved for voluntary choice of activities, combining a feeling of satisfaction, wellbeing, and fun ${ }^{3}$. Physical activity during leisure time allows the search for physical exercises programs, that is, structured activities aimed at improving physical capabilities. In addition to physiological benefits, they also provide the possibility of interacting with friends and family members, and selecting pleasant and safe environments ${ }^{3}$.

In this study, we found that physical activity at work was a protective factor for the occurrence of stress in men. Thus, a hypothesis can be raised that, as some studies have already shown ${ }^{17,19}$, for women, the work environment is more conducive to the occurrence of stress than for men. For the latter, physical activity at work was inversely associated with the occurrence of stress.

In this study, the fact that stress occurrences tended to decrease as the number of domains that contained physical activity increased reinforces the importance of a physically active lifestyle for the maintenance of psychological well-being and mental health ${ }^{9}$. This finding can be explained by the set of changes in hormone levels, such as an increased release of beta-endorphin and ACTH (adrenocorticotropic hormone), which are responsible for improving mood, sleep, and the feeling of well-being, and making acute organic adjustments in brain receptors ${ }^{25}$.

Some types of leisure time physical activities were significantly associated with a lower occurrence of stress in women, regardless of their age, marital status, education level and family income. The types of leisure time physical activities associated with a lower occurrence of stress in both sexes were sports, walking, and gymnastics/weight lifting. This is in line with other studies that show that, regardless of their intensity, there is a relationship between stress reduction and aerobic exercises ${ }^{9,3}$, and lower stress perception at work and the practice of muscle-resistance exercises ${ }^{26}$.

Participation in dance was associated with lower stress occurrence in women. This may be due to behavioral aspects. According to a study by Mejía ${ }^{27}$ in which $76.7 \%$ of the study sample were women, the occurrence of stress in workers decreased when they participated in dance activities. For men, in turn, participation in jogging and cycling were significantly associated with lower stress. This indicates that moderate-to-vigorous-intensity physical activity yields better results for the overall health of adult men ${ }^{28,29}$.

Participation in yoga, tai chi chuan and stretching exercises - activities that are well recognized as associated with lower stress prevalences ${ }^{30}$ - was also associated 
with the lowest occurrence of stress in men, and the second lowest occurrence of stress in women. These data, however, should not be considered very reliable due to wide confidence intervals. These results raise the hypothesis that this event may be a reflection of the total number of participants who reported one of these activities as their main activity during leisure time. Considering the total of $0.21 \%$ of the sample, this separately represented $0.39 \%$ of females and $0.13 \%$ of males.

This study had some limitations. Since this was a cross-sectional study, its reverse causality affects the subjectivity of the measurement of stress, which was performed using a single question, without the use of biomarkers. Moreover, the summarized manner in which physical activity in different domains was investigated, with different measures of physical activity and no information on its duration or intensity, as well as the use of socioeconomic references relevant to the minimum wage of the sample could affect future comparisons between categories of the different domains. Another limitation is the fact that an analysis by conglomerates was not carried out, due to the complex, two-step sampling design (industry and company size). This may have resulted in an inaccurate estimation, however small, of some of the data presented here. Nevertheless, these issues did not prevent us from observing significant results, especially with regard to the association between physical activity in the leisure time domain and lower incidences of stress in a representative sample of Brazilian workers.

Stress in the workplace is a major quality-of-life factor for workers, and for the employer, it results in problems such as work absenteeism, emotional disorders and reduced performance ${ }^{22}$. It may also have consequences in contexts that range beyond the individual worker routine, leading to losses in products and services produced by the sectoral working teams, and consequently, by the company.

We conclude that physical activity, especially during leisure time, and participation in activities such as sports among women, and jogging among men, were associated with lower stress occurrences. This can be explained by the fact that, when performed with greater intensity and frequency, physical activity promotes health and well-being among workers and should be encouraged in the work environment. We recommend that future studies conduct analyses with more accurate measurements, and investigate more closely how stress affects the work environment and occupational health, in order to implement specific measures and actions to change this reality.

\section{Financing}

Social Services for the Industry/National Department, Coordenação de Aperfeiçoamento de Pessoal de Nível Superior (Capes)/Conselho Nacional de Desenvolvimento Científico e Tecnológico (CNPq)

\section{References}

1. Selye H. The stress of life. New York (NY): McGraw-Hill, 1956.

2. Carmelo SHH, Angerami ELS. Sintomas de estresse nos trabalhadores atuantes em cinco núcleos de saúde da família. Rev Latino-Am Enfermagem. 2004; 12(1):14-21.

3. Nahas MV. Atividade física, saúde e qualidade de vida: conceitos e sugestões para um estilo de vida ativo. $5^{\text {a }}$ Edição. Londrina: Midiograf; 2010.

4. Prince M, Patel V, Saxena S, Maj M, Maselko J, Phillips MR, et al. No health without mental health. Lancet. 2007; 370:859-77. 
5. Castiel LD. O Estresse na Pesquisa Epidemiológica: o Desgaste dos Modelos de Explicação Coletiva do Processo Saúde-Doença. Ciênc Saúde Coletiva. 2005; 15(Suplemento):103- 20.

6. Viana MS, Andrade A, Back AR, Vasconcellos DIC. Nível de atividade física, estresse e saúde em bancários. Motricidade. 2010; 6(1):19-32.

7. Kopp MS, Thege BK, Balog P, Stauder A, Salavecz G, Rózsa S, et al. Measures of stress in epidemiological research. J Psychosom Res. 2010; 69(1): 211-25.

8. Paschoal T, Tamayo A. Validação da Escala de Estresse no Trabalho. Estud Psicol. (Campinas). 2004; 9(1): 45-52.

9. American College Of Sports Medicine (ACSM). ACSM's Exercise Management for Persons with Chronic Disease and Disabilities. 3.ed. Champaign: Human Kinetics, 2009.

10. Minayo MCS, Assis SG, Oliveira RVC. Impacto das atividades profissionais na saúde física e mental dos policiais civis e militares do Rio de Janeiro (RJ, Brasil). Ciênc Saúde Coletiva. 2011; 16(4):2199-209.

11. Jex SM. Stress and job performance. Londres: Sage, 1998.

12. Harvey SB, Hotopf M, Overland S, Mykletun A. Physical activity and common mental disorders. B J Psych. 2010; 197(1):357-64.

13. Colégio Americano De Medicina Do Esporte (ACSM). Diretrizes do ACSM para os testes de esforço e sua prescrição. 7. ed. Rio de Janeiro (RJ): Guanabara Koogan, 2007. 266p.

14. Freitas AR, Carneseca EC, Paiva CE, Paiva BSR. Impact of a physical activity program on the anxiety, depression, occupational stress and burnout syndrome of nursing professional. Rev Latino-Am Enfermagem. 2014; 22(2):332-36.

15. Asztalos M, Wijndaele K, De Bourdeaudhuij I, Philippaerts R, Matton L, Duvigneaud $\mathrm{N}$, et al. associações específicas entre tipos de atividade física e componentes de saúde mental. J Med Sci Sport. 2009; 12 (4): 468-74.

16. Nahas MV, et al. Estilo de vida e hábitos de lazer dos trabalhadores das indústrias brasileiras: relatório geral. Brasília: SESI/DN, 2009. 163 p.

17. Barros MVG, Nahas MV. Comportamentos de risco, auto-avaliação do nível de saúde e percepção de estresse entre trabalhadores da indústria. Rev Saúde Pública. 2001; 35(6):554-63.

18. Fonseca SA. Inatividade física no lazer e outros fatores de risco à saúde em industriários catarinenses, 1999-2004. [Dissertação de Mestrado]. Florianópolis: Universidade Federal de Santa Catarina, 2005.

19. Farah BQ, Barros MVG, Farias Júnior JC, Ritti-Dias RM, Lima RA, Barbosa JPAS, et al. Percepção de estresse: associação com a prática de atividades físicas no lazer e comportamentos sedentários em trabalhadores da indústria. Rev Bras Educ Fís Esp. 2013; 27(2):225-34.

20. Lipp M EM, Tanganelli MS. Stress e qualidade de vida em magistrados da justiça do trabalho: Diferenças entre homens e mulheres. Psicol Reflex Crit. 2002; 15:537-48.

21. Goulart Junior E, Lipp MEN. Estresse entre professoras do ensino fundamental de escolas públicas estaduais. Psicol Est. 2008; 13(4): 847-57.

22. Sadir MA, Bignotto MM, Lipp MEN. Stress e qualidade e vida: influência de algumas variáveis pessoais. Paideia. 2010; 20(45):73-81.

23. Sinyor D, Schwartz SG, Peronnet F, Brisson G, Seraganian P. Aerobic fitness level and reactivity to psychosocial stress: physiological, biochemical, and subjective measures. Psychosom Med. 1983; 45(3):205-17.

24. Otha M, Tetsuya M, Mishima N, Ikeda M. Effect of the Physical Activities in Leisure Time and Commuting to Work on Mental Health. J Occup Health. 2007; 49:46-52.

25. Simon RW. Gender, multiple roles, role meaning, and mental health. J Health Soc Behav.1995; 36(1):182-94.

26. Bretland RJ, Thorsteinsson EB. Reducing workplace burnout: the relative benefits of cardiovascular and resistance exercise. PeerJ. 2015; 3: e891.

27. Mejía FM. Efectos de la danza terapéutica en el control del estrés laboral en adultos entre 25 y 50 años. Hacia Promoc Salud. 2011, 16(1):156-74. 
28. Paffenbarger Junior RS, Hyde RT, Wing AL, Lee IM, Jung DL, Kampert JB. The association of changes in physical-activity level and other lifestyle characteristics with mortality among men. N Engl J Med. 1993; 328(8):538-45.

29. Pitanga FJG. Epidemiologia, atividade física e saúde. Rev Bras Ciên e Mov. 2002;10(3):49-54.

30. Jindani FA, Khalsa GF. A Yoga Intervention Program for Patients Suffering from Symptoms of Posttraumatic Stress Disorder: A Qualitative Descriptive Study. J Altern Complement Med. 2015;21(7):401-08.

ENDEREÇO PARA

CORRESPONDÊNCIA

MARINA CHRISTOFOLETTI DOS SANTOS

marinachriss@outlook.com
Campus Universitário Reitor João

David Ferreira Lima, Coordenadoria de

Pós-Graduação em Educação Física, s/n.

Bairro Trindade, Florianópolis, Santa

Catarina, Brazil, CEP: 88040-900

Phone: +55 (48) 3721.9926

Fax +55 (48) 3721-9792
RECEBIDO 03/10/2015

REVISADO $17 / 11 / 2015$

APROVADO $\quad 07 / 12 / 2015$ 